\title{
Association of History Taking and Accuracy of the Interpretation of Cervical and Lumbar Magnetic Resonance Imaging
}

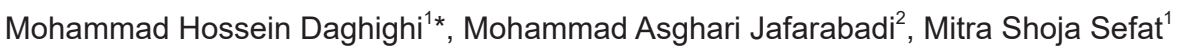 \\ ${ }^{1}$ Department of Radiology, Faculty of Medicine, Tabriz University of Medical Sciences, Tabriz, Iran; ${ }^{2}$ Department of Biostatistics, \\ Tabriz University of Medical Sciences, Tabriz, Iran
}

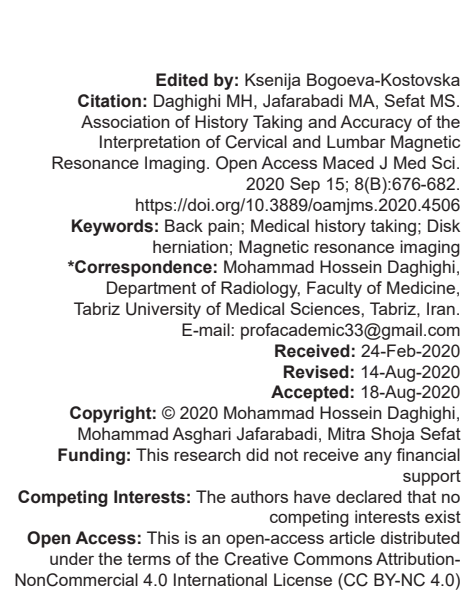

\section{Introduction}

For the first time, magnetic resonance imaging (MRI) has allowed intrathecal observation in a noninvasive manner [1]. The non-specific low back pain is one of the most common indications for the MRI requests. The degenerative disk disease is an important issue in occupational health that can lead to worrisome state especially in adults [2], [3], [4]. MRI reports are important in terms of therapeutic decisions, and incorrect reports may result in invasive or non-invasive, but unnecessary, interventions [5], [6]. Incurring additional financial costs to the patient, which ultimately undermines the national economy, are another consequence of inaccurate diagnoses [7]. Today with the remarkable advancement of technology a new imaging modalities including $\mathrm{MRI}$ is needed for the therapeutic decision-making and surgical interventions [8]. Therefore, accuracy in MRI reports is very important. One of the effective factors in the accuracy of MRI reports is the medical history of patients in radiology request forms, which can be helpful or, on the other hand, lead to bias and haste in the writing of reports by residents, especially in educational centers with a high workload, so that the residents may use the histories and refrain from classic and systematic reading of MRI images, which would increase the number of false negative and false positive cases and, contrary to popular belief, reduce the accuracy of the reports [9], [10], [11], [12]. The radiologist does not have direct contact with the patient for medical history and physical examination, and thus, an incomplete and inaccurate history may also be misleading [13]. Therefore, the purpose of this study was to compare the accuracy of MRI reports by attending physicians and residents, once with history and once again without history. It should be noted that no similar study has been conducted in Iran so far on the role of medical histories on the accuracy of $\mathrm{MRI}$ reports. The question arises as to whether the existence of medical histories in MRI requests is helpful, or on contrary, is confounding and causes haste, and 
whether the existence of false histories does not make the less experienced interpreter report inaccurate and unnecessary diagnoses [14], [15], [16], [17], [18], [19]. Some studies have been conducted in this area, including the study of Berbaum et al., who reviewed the effect of clinical history on chest X-ray (CXR) interpretation, concluding that the quality of reports was unaffected by the histories [20]. Another study examined the effect of history on CXR in children with bronchiolitis and proved that positive histories could increase the risk of false positive results [21]. Furthermore, the study of effect of the record and professional experiences in the positron emission tomography and computed tomography (CT) scan report, which proved in this study showed that professional experience did not play a significant role in the accuracy of the reports [22]. Another study demonstrated the effect of clinical parameters on the success of MR guided wire localization [23]. Based on the controversial results of past research and considering the importance of the issue and the lack of a similar study in Iran, we decided in this study to examine the role of medical history and the validity of the history in the accuracy of the cervical and lumbar MRI reports.

\section{Materials and Methods}

This study is a comparative study on 150 patients which was performed among patients who were referred to the Imam Reza Hospital Tabriz-Iran with the back or neck pain or the symptoms of radiculopathy and candidate for MRI. The subject underwent MRI examinations for cervical and lumbar spine. The primary outcome (images) was first reported by the $2^{\text {nd }}$ and $3^{\text {rd }}$ years residents who know the clinical history of the patients. The reports were checked according to the checklist and variables and then reviewed by the attending physician. After about 4-6 months, the MRIs of the same patients were again submitted to the $2^{\text {nd }}$ and $3^{\text {rd }}$ years residents by eliminating the histories, and the results were recorded. Furthermore, after the modification by the attending physicians, the changes were recorded. After completion, the reports along with the histories for 150 patients were compared with the reports of the same patients by eliminating the history. Items such as disk surface, herniation side, hernia level, and the degree and type of stenosis were compared. The benchmark for comparing both groups is the MRI and report of the experienced attending physicians on the cervical and lumbar MRI.

All ethical issues such as conflict of interest, misconduct, co-authorship, and double submission were considered carefully. Ethical permission for the study was obtained from the Ethics Committees of Tabriz University of Medical Sciences. The ethical principles of autonomy, beneficence, non-maleficence, fidelity, and confidentiality were adhered to. During the process, both residents and attending physicians were unaware of the fact that they participated in this study.

\section{Statistical analysis}

The distributional properties of continuous data were expressed as mean \pm standard deviation. The categorical data were presented by frequency and percentage. Patient characteristic data before and after awarding of the clinical history of the patients were compared using paired t-test (for continuous variables). Moreover, other appropriate statistical tests (Chisquare test and Fisher's exact test) applied if needed. Data analysis was performed using SPSS 23 software at a significant level of 0.05 .

\section{Results}

\section{patients \\ Demographic features of the study}

One hundred and fifty patients were enrolled according to inclusion criteria with the mean age of $42.56 \pm 10.65$ years. Eighty-seven (58\%) were female and $63(42 \%)$ were male (Table 1$)$. The largest age group was formed by those between 40 and 50 years old $(34.66 \%)$. The mean age of males was 47.66 and that of females was 37.46 years. The studied patients had no history of trauma and there was no intervertebral disk retropulsion.

Table 1: Morphology of disk herniation in lumbar and cervical MRI

\begin{tabular}{lll}
\hline Disk herniation & Morphology & Number \\
\hline Cervical & Protrusion & 64 \\
& Extrusion & 6 \\
& Bulging & 36 \\
Lumbar & Protrusion & 30 \\
& Extrusion & 9 \\
& Bulging & 68 \\
\hline MRI: Magnetic resonance imaging. & &
\end{tabular}

\section{Clinical and paraclinical characteristics of study patients}

The most common symptom of the patients was the waist and neck pain and afterward, the patients complained of sensory impairment of lower and upper extremities. In cases of cervical hernia, most of the symptoms were the pain in the arm or paresthesia in the dermatome where the nerve was involved. Among these 150 cases, only seven cases were referred with paraplegia. Most of the patients referred as the outpatient with primary symptoms and were diagnosed with herniation disk with different levels of disk involvement. Gender did not affect most MRI findings $(p<0.05)$. The age of people with MRI change was 
higher than those without the change, and the changes were generally higher in female subjects $(p<0.05)$. In the age range of 60 years and older, the abnormal MRI was more than $50 \%$ compared with normal MRI.

\section{Paraclinical findings (MRI reports) before receiving a biography of patients}

The patients were referred with low back pain and neck pain and subjected to MRI. The $2^{\text {nd }}$ and $3^{\text {rd }}$ year residents and the attending physicians first reported the images without regarding the patient history. A total of 380 disks were evaluated in 150 patients. Among these, 109 cases of lumbar MRI and 41 cases of cervical MRI were performed. Among the cases of lumbar disk herniation, 68 cases (28.8\%) of bulging alone, 30 cases $(7.8 \%)$ of protrusion, and $9(2 \%)$ extrusion cases were reported. In the cases where bulging was seen, it did not generally have protrusion, and the combination of these two included a small percentage.

The number of cases of cervical and lumbar vertebral hernia morphology is presented in the Table 1.

In the lumbar MRI reports 58 cases $(40.7 \%)$ of central (median) involvement, 20 cases $(21.1 \%)$ of only right-side involvement and 31 cases $(38.2 \%)$ of only leftside involvement were existed. Furthermore, in cases of cervical MRI, before being aware of patient histories, 18 cases $(43.9 \%)$ of central involvement, 11 cases $(26.82 \%)$ of right-side involvement, and 12 cases $(29.26 \%)$ of only left-side involvement were reported. Seventeen cases (11.33\%) had osteophytes, mostly on the L4-L5 and L1-L2 levels. Twenty-eight items (18.66\%) had spondylolisthesis, mostly on L5-S1 and L4-L5 levels. Thirty-three cases $(23.52 \%)$ had hypertrophy of ligamentum flavum, which was higher on L4-L5 levels. The following table shows the frequency of this radiologic finding in terms of gender. Osteophytes were seen in most age groups, but it was significantly less in the 30-40 year age group and was more frequent in older ages (50-70 years).

Nineteen cases (6.8\%) had L1-L2 disk involvement, mostly in the form of bulging, and in 1 case $(0.4 \%)$ it resulted in stenosis, mainly in the central area. Twenty-two (7.9\%) cases had L2-L3 disk involvement, mostly in the form of bulging, and in 2 cases $(0.7 \%)$ resulted in stenosis generally in the central area. There were $56(20 \%)$ cases of L3-L4 disk involvement, which was mainly protrusion, leading to stenosis in 11 cases generally in the central area. There were $146(52.1 \%)$ cases of L4-L5 disk involvement, which was mainly protrusion and resulted in stenosis in 47 cases (16.8\%). Eighty-two cases (6.8\%) had L5-S1 involvement, which was mainly protrusion, and resulted in stenosis in 24 cases (8.6\%), mainly in the left paracentral area.

The spinal stenosis is reported as mild, moderate, and severe levels. The frequency and severity of spinal stenosis at different vertebrae levels involved in the study subjects are listed in Table 2.
Table 2: Frequency and severity of canal stenosis in different lumbar vertebrae in the study patients

\begin{tabular}{lllll}
\hline Level involved & Canal stenosis & & & \\
\cline { 2 - 5 } & $\begin{array}{l}\text { Mild } \\
\text { stenosis }(\mathrm{n})\end{array}$ & $\begin{array}{l}\text { Moderate } \\
\text { stenosis }(\mathrm{n})\end{array}$ & $\begin{array}{l}\text { Severe } \\
\text { stenosis }(\mathrm{n})\end{array}$ & \\
\hline L1-L2 & 0 & 3 & 1 & $4(2.63)$ \\
L2-L3 & 1 & 3 & 1 & $5(5.26)$ \\
L3-L4 & 3 & 10 & 5 & $18(28.94)$ \\
L4-L5 & 8 & 19 & 11 & $38(63.15)$ \\
Total & 12 & 35 & 18 & $65(100)$ \\
\hline
\end{tabular}

Disk herniation has many different etiologic factors, of which four major cases in the lumbar and cervical MRI are mentioned in this study, and the values are listed in Tables 3 and 4.

Table 3: Etiologic factors of lumbar spinal stenosis

\begin{tabular}{lll}
\hline Etiologic factor & Stenosis severity & Number \\
\hline Primary & - & 4 \\
DOCP induced & Mild & 7 \\
& Moderate & 4 \\
Caused by disk herniation & Severe & 13 \\
& Mild & 20 \\
More than one etiology & Severe & 12 \\
Total & - & 5 \\
\hline
\end{tabular}

Left posterolateral protrusion and left extrusion were the most commonly observed morphology in patient's cervical MRI. Furthermore, 36 cases of disk bulging were reported. Frequency of cervical vertebrae levels (level of involvement) based on MRI report without clinical history showed that $\mathrm{C} 6-\mathrm{C} 7$ were the most common involved levels.

Table 4: Spinal cord stenosis with different etiologies in cervical MRI

\begin{tabular}{lll}
\hline Etiologic factor & Stenosis severity & Number \\
\hline Primary & - & 3 \\
DOCP induced & Mild & 7 \\
& Moderate & 5 \\
Caused by disk herniation & Severe & 4 \\
& Mild & 9 \\
More than one etiology & Severe & 3 \\
Total & - & 2 \\
\hline
\end{tabular}

MRI: Magnetic resonance imaging.

\section{Paraclinical findings (MRI report) after obtaining history from the patients}

After 6 months, the same films were given to the same residents and attending physicians for interpretation, with the difference that this time they knew the history of the patients. The severity of spinal stenosis in cervical and lumbar MRI cases is presented in Table 5 before and after the awareness of the reporting person of the medical history.

Table 5: The severity of vertebral canal stenosis reported before and after the history of patients

\begin{tabular}{|c|c|c|c|c|c|}
\hline \multirow[t]{3}{*}{ Canal stenosis } & \multicolumn{4}{|c|}{ (Patient number) history taking } & \multirow[t]{3}{*}{$\mathrm{p}$-value } \\
\hline & \multicolumn{2}{|l|}{ Before } & \multicolumn{2}{|l|}{ After } & \\
\hline & Cervical & Lumbar & Cervical & Lumbar & \\
\hline Mild & 28 & 4 & 23 & 5 & 0.001 \\
\hline Moderate & 5 & 21 & 8 & 19 & 0.000 \\
\hline Severe & 7 & 13 & 9 & 14 & 0.04 \\
\hline
\end{tabular}

The morphology of cervical and lumbar hernia was also compared in Table 6 before and after the history. Table 7 presents the spinal stenosis etiologies in the studied patients before and after awareness of history. The herniation side of the cervical and lumbar 
Table 6: Vertebral disk herniation morphology in MRIs reported before and after the history taking

\begin{tabular}{|c|c|c|c|c|c|}
\hline \multirow[t]{3}{*}{ Canal stenosis } & \multicolumn{4}{|c|}{ (Patient number) history taking } & \multirow[t]{3}{*}{$\mathrm{p}$-value } \\
\hline & \multicolumn{2}{|c|}{ Before } & \multicolumn{2}{|l|}{ After } & \\
\hline & Cervical & Lumbar & Cervical & Lumbar & \\
\hline Protrusion & 64 & 30 & 59 & 36 & 0.000 \\
\hline Extrusion & 6 & 9 & 11 & 10 & 0.03 \\
\hline Bulging & 56 & 24 & 24 & 56 & 0.01 \\
\hline
\end{tabular}

disks is also listed in Table 8 . The results of these findings are described by the reporting person with different experience years in Tables 9-12. The Kappa agreement coefficient for the initial and final findings was - 0.88. The findings showed that the reporting

Table 7: Causes of canal stenosis in the study patients before and after history taking

\begin{tabular}{|c|c|c|c|c|c|}
\hline \multirow[t]{3}{*}{ Etiologic factors } & \multicolumn{4}{|c|}{ (Patient number) history taking } & \multirow[t]{3}{*}{$p$-value } \\
\hline & \multicolumn{2}{|l|}{ Before } & \multicolumn{2}{|l|}{ After } & \\
\hline & Cervical & Lumbar & Cervical & Lumbar & \\
\hline \multicolumn{6}{|l|}{ Disk herniation } \\
\hline Mild & 9 & 20 & 11 & 24 & 0.02 \\
\hline Severe & 3 & 12 & 5 & 16 & 0.00 \\
\hline \multicolumn{6}{|l|}{ DOCP } \\
\hline Mild & 7 & 7 & 10 & 12 & 0.05 \\
\hline Moderate & 5 & 4 & 8 & 10 & 0.001 \\
\hline Severe & 4 & 13 & 6 & 19 & 0.000 \\
\hline Primary & 3 & 4 & 3 & 7 & 0.06 \\
\hline More than one etiology & 2 & 5 & 3 & 7 & 0.00 \\
\hline
\end{tabular}

person, before awareness of the patient history, mentioned some cases of hernia or other findings in the MRI report, which, after 6 months and by matching the history of patients, there was a significant difference between the patient histories and the pathology found in MRI.

Table 8: Side of cervical and lumbar disk herniation in the MRI reports

\begin{tabular}{|c|c|c|c|c|c|}
\hline \multirow[t]{3}{*}{ Side of herniation } & \multicolumn{4}{|c|}{ (Patient number) history taking } & \multirow{3}{*}{ p-value } \\
\hline & \multicolumn{2}{|l|}{ Before } & \multicolumn{2}{|l|}{ After } & \\
\hline & Cervical & Lumbar & Cervical & Lumbar & \\
\hline Central & 18 & 58 & 10 & 53 & 0.2 \\
\hline Left & 31 & 31 & 19 & 22 & 0.02 \\
\hline Right & 11 & 20 & 12 & 34 & 0.05 \\
\hline
\end{tabular}

\section{Discussion}

Low back pain is one of the common causes for the referral of patients and requests for medical services, and $80-90 \%$ of adults $(50 \%$ of the employed population each year) had a record of back pain [24], [25]. The prevalence in different epidemiological studies varied

Table 9: The relationship between MRI reports of the $2^{\text {nd }}$ year radiology residents before and after the history taking

\begin{tabular}{llll}
\hline Variables & $\begin{array}{l}\text { No history } \\
\text { (Percent reported) }\end{array}$ & $\begin{array}{l}\text { With history } \\
\text { (Percent reported) }\end{array}$ & p-value \\
\hline Herniation & & & \\
$\quad$ Protrusion & 40.53 & 58.90 & 0.00 \\
$\quad$ Extrusion & 29.35 & 11.64 & 0.00 \\
$\quad$ Bulging & 30.12 & 29.46 & 0.8 \\
$\quad$ Canal stenosis frequency & 51.09 & 70.8 & 0.2 \\
Canal stenosis etiology & & & \\
$\quad$ Primary & 18.9 & 14.69 & 0.5 \\
$\quad$ Herniation induced & 31.79 & 40.18 & 0.00 \\
$\quad$ DOCP induced & 45.20 & 33.16 & 0.02 \\
$\quad$ More than 1 etiology & 4.11 & 11.97 & 0.04 \\
Side of herniation & & & \\
$\quad$ Central & 26.3 & 29.41 & 0.1 \\
$\quad$ Left & 40.52 & 27.09 & 0.00 \\
$\quad$ Right & 32.7 & 43.5 & 0.04 \\
\hline MRI: Magnetic resonance imaging. & & &
\end{tabular}

between $7.5 \%$ and $36 \%$, with the highest prevalence in the 45-60 year age group [26], [27], [28], [29]. The neck pain also has $10-20 \%$ prevalence in the adult population. The degenerative changes in cervical vertebrae are the most common causes of acute and chronic neck pains [30]. MRI is a non-invasive method and the most sensitive imaging trial for the

Table 10: The relationship between MRI reports of the $3^{\text {rd }}$ year radiology residents before and after the history taking

\begin{tabular}{llll}
\hline Variables & $\begin{array}{l}\text { No history } \\
\text { (Percent reported) }\end{array}$ & $\begin{array}{l}\text { With history } \\
\text { (Percent reported) }\end{array}$ & p-value \\
\hline Herniation & & & \\
$\quad$ Protrusion & 44.96 & 53.60 & 0.03 \\
$\quad$ Extrusion & 5.95 & 13.06 & 0.05 \\
$\quad$ Bulging & 49.09 & 33.34 & 0.00 \\
$\quad$ Canal stenosis frequency & 66.3 & 71.5 & 0.6 \\
Canal stenosis etiology & & & \\
$\quad$ Primary & 12.00 & 15.98 & 0.1 \\
$\quad$ Herniation induced & 39.64 & 32.09 & 0.05 \\
$\quad$ DOCP induced & 33.50 & 41.06 & 0.02 \\
$\quad$ More than 1 etiology & 14.86 & 10.87 & 0.09 \\
Side of herniation & & & \\
$\quad$ Central & 40.31 & 45.6 & 0.4 \\
$\quad$ Left & 20.89 & 23.5 & 0.2 \\
$\quad$ Right & 38.8 & 30.9 & 0.08 \\
\hline MRI: Magnetic resonance imaging. & & & \\
\hline
\end{tabular}

evaluation of the spinal cord and vertebra, which exactly shows neural structures, particularly compared to CT scan [31], [32]. Such imaging modality can help clinicians to identify a better medical approach and clinical judgment. However, it is important to state that in most circumstances the indication for surgery cannot be established only on the structural changes observed via MRI.

Table 11: The relationship between MRI reports of the experienced (expert) radiology professors before and after the history taking

\begin{tabular}{llll}
\hline Variables & $\begin{array}{l}\text { No history } \\
\text { (Percent reported) }\end{array}$ & $\begin{array}{l}\text { With history } \\
\text { (Percent reported) }\end{array}$ & p-value \\
\hline Herniation & & & \\
$\quad$ Protrusion & 44.13 & 48.46 & 0.2 \\
$\quad$ Extrusion & 7.04 & 10.71 & 0.1 \\
$\quad$ Bulging & 48.82 & 40.81 & 0.06 \\
$\quad$ Canal stenosis frequency & 70.05 & 75.07 & 0.6 \\
Canal stenosis etiology & & & \\
$\quad$ Primary & 6.8 & 9.09 & 0.09 \\
$\quad$ Herniation induced & 33.54 & 36.36 & 0.2 \\
$\quad$ DOCP induced & 42.89 & 44.44 & 0.1 \\
$\quad$ More than 1 etiology & 16.77 & 5.55 & 0.02 \\
Side of herniation & & & \\
$\quad$ Central & 49.67 & 45 & 0.2 \\
$\quad$ Left & 28.10 & 31.82 & 0.1 \\
$\quad$ Right & 20.23 & 23.18 & 0.8 \\
\hline
\end{tabular}

The primary finding of this study is that knowing the medical history of the patient creates a bias in the final reports of MRI. If an unusual or contradictory finding related to the MRI reports was found, there

Table 12: The relationship between MRI reports of the less experienced radiologist before and after the history taking

\begin{tabular}{llll}
\hline Variables & $\begin{array}{l}\text { No history } \\
\text { (Percent reported) }\end{array}$ & $\begin{array}{l}\text { With history } \\
\text { (Percent reported) }\end{array}$ & p-value \\
\hline Herniation & & & \\
$\quad$ Protrusion & 45.36 & 50.9 & 0.1 \\
$\quad$ Extrusion & 8.09 & 11.56 & 0.2 \\
$\quad$ Bulging & 46.55 & 37.54 & 0.05 \\
$\quad$ Canal stenosis frequency & 74.65 & 79.05 & 0.7 \\
Canal stenosis etiology & & & \\
$\quad$ Primary & 6.8 & 9.09 & 0.23 \\
$\quad$ Herniation induced & 33.87 & 36.02 & 0.4 \\
$\quad$ DOCP induced & 39.25 & 45.61 & 0.09 \\
$\quad$ More than 1 etiology & 20.08 & 9.28 & 0.05 \\
Side of herniation & & & \\
$\quad$ Central & 48.3 & 46 & 0.5 \\
$\quad$ Left & 30.09 & 34.6 & 0.09 \\
$\quad$ Right & 21.61 & 19.4 & 0.1 \\
\hline MRI: Magnetic resonance imaging. & & &
\end{tabular}


should be an examination of presence of confounding and interfering factors. Such phenomenon may well be the subject of a clinical review bias.

The clinical review bias occurs when the researcher becomes biased by knowing a golden standard test, which affects the results and final findings [33]. So far, few studies have been conducted in Iran regarding the accuracy of MRI reports in patients with disk herniation before and after getting clinical history. However, the results of our study are in line with the few results of studies conducted in this field, suggesting that the clinical data existing in the MRI interpretation make intervention [34], [35], [36], [37].

Tudor et al. noted that the bias in clinical review led to a slight increase in the specificity of this imaging technique [38], while Berbaum et al. did not find any contribution for the effect of this interfering factor [39]. In this study, the most common findings in the pathology of disk hernia were protrusion and bulging, none of which was related to the gender of the individuals. In the reports, the lumbar and cervical MRI were the most frequent cases of central involvement, which was largely similar to the results of the study by Ebeling et al. [39]. According to the reports by the residents and attending physicians in this study, the most cervical level involved was C6-C7. The highest level of lumbar involvement was L4-L5. The reason for more frequent disk protrusion in these levels is the greater mechanical pressure. These findings are similar to those of previous studies [39], [40], [41], [42]. The family record of low back pain and the familial susceptibility to the hernia disks have been shown in other studies in the world, such as Matsui et al. and Scapinelli et al. studies [43], [44]. In the study of Videman et al., the reduced signal of the secondary vertebral tissue to drying out and protrusion is the findings that begin at the age of 35 and increase with the age of the patient [45]. In our study, the highest involved levels were the L4-L5 osteophyte followed by L1-L2. The formation and occurrence of osteophytes can be due to different causes; age-related conditions such as degenerative disk changes, osteoarthritis and spinal stenosis, and rupture may be among the factors. Chanapa et al. conducted a study on 180 patients with low back pain and lumbar osteophytes. In the results, they mentioned that the highest prevalence of osteophytes was in the L4 vertebral level, which had the highest correlation with patient age [46]. Spinal stenosis following spinal disk herniation is one of the main causes of neurosurgeon surgeries at high ages and is an important etiologic factor in the occurrence of pain and disability in these individuals [20], [47], [48]. Morshed et al., in a study with a sample of 48 patients, reported about six cases of stenosis induced by lumbar disk herniation, of which one was partial stenosis and six cases were complete stenosis [49]. In our study, the highest prevalence of stenosis was in L4-L5 lumbar levels, which accounts for 38 cases $(61.15 \%)$ of all stenosis cases. Among these, most cases of moderate stenosis were reported. In the cervical vertebrae, 40 cases of stenosis were reported, which are often the mild cases. The stenosis of spinal cord has different etiologies, including congenital, secondary, and concomitant congenital-secondary stenosis [22], [23], [50], [51]. In our study, the cause of lumbar spinal stenosis was most commonly due to disk herniation followed by the DOCP induced stenosis. In the cervical vertebrae, the highest etiologic factor of stenosis is induced by DOCP. The results of this study showed that there was a statistically significant difference between the reported cases of spinal stenosis, herniation morphology, herniation etiology, and herniation side. The analysis of these results suggests that the accuracy of the reports and findings was reduced after that the residents and attending physicians became aware of the patient history. The residents missed some cases by reading the histories and also exaggerated some cases in the reports, which showed false positive and false positive results in the reports of the residents after knowing the medical history of the patients. For example, the involvement levels and the reported stenosis percentage can be mentioned. In cases of reports prepared by attending physicians, there was no significant difference in most of the studied variables, which indicates that; first, the accuracy of MRI reports is increases with the work experience so that the accuracy of reports prepared by the attending physicians in order is higher than the $3^{\text {rd }}$ and $2^{\text {nd }}$ year residents. The reason for this should be due to the fact that knowing a history concentrates the specialist's mind on a particular case and limits him around a minor issue and the ability to reason and think wider with other involved factors and the possibility of other findings will be denied. The results of this study showed that there was no significant difference between the reports by the attending physicians after knowing the history of the patient.

Some limitations of the present investigation exist due to the study design and practical constraints. There were few similar studies in this field, which made it difficult to compare the results and interpret the findings. Moreover, the conclusions and findings need further verification by larger scale studies.

\section{Conclusion}

The results of this study showed that although complete and accurate medical histories are an important part of the patient's diagnosis and treatment process, this does not significantly help the radiologists in providing accurate and complete reports. The experience of specialist is undoubtedly an important factor in this regard. It is recommended that the residents and attending physicians of the field of 
radiology, before receiving the patient's clinical history, accurately look at the MRI images so that they could report better results.

\section{References}

1. Ganesan S, Acharya AS, Chauhan R, Acharya S. Prevalence and risk factors for low back pain in 1,355 young adults: A crosssectional study. Asian Spine J. 2017;11(4):610-7. https://doi. org/10.4184/asj.2017.11.4.610

PMid:28874980

2. Shmagel A, Foley R, Ibrahim H. Epidemiology of chronic low back pain in US adults: Data from the 2009-2010 national health and nutrition examination survey. Arthritis Care Res (Hoboken). 2016;68(11):1688-94. https://doi.org/10.1002/acr.22890 PMid:26991822

3. Bressler HB, Keyes WJ, Rochon PA, Badley E. The prevalence of low back pain in the elderly. A systematic review of the literature. Spine (Phila Pa 1976). 1999;24(17):1813-9. https:// doi.org/10.1097/00007632-199909010-00011

PMid: 10488512

4. Jandrić S, Antić B. Low back pain and degenerative disc disease. Med Pregl. 2006;59(9-10):456-61. https://doi.org/10.2298/ mpns0610456j

PMid:17345822

5. Radziszewski KR. Physical exercise in treatment of patients with lumbar discopathy. Ortop Traumatol Rehabil. 2007;9(1):98-106. PMid: 17514181

6. Radziszewski KR. Comparative retrospective analysis of pain afflictions in patients with lumbar discopathy receiving conservative or operative therapies. Pol Merkur Lekarski. 2006;21(124):335-40.

PMid:17205771

7. Monie AP, Fazey PJ, Singer KP. Low back pain misdiagnosis or missed diagnosis: Core principles. Man Ther. 2016;22:68-71. https://doi.org/10.1016/j.math.2015.10.003

PMid:26521215

8. Aly TA, Aboramadan MO. Efficacy of delayed decompression of lumbar disk herniation causing cauda equina syndrome. Orthopedics. 2014;37(2):e153-6. https://doi. org/10.3928/01477447-20140124-18

PMid:24679201

9. Fu M, Ye Q, Jiang C, Qian L, Xu D, Wang Y, et al. The segmentdependent changes in lumbar intervertebral space height during flexion-extension motion. Bone Joint Res. 2017;6(4):245-52. https://doi.org/10.1302/2046-3758.64.bjr-2016-0245.r1 PMid:28450317

10. Lian C, Gao B, Wu Z, Qiu X, Peng Y, Liang A, et al. Collagen Type II is downregulated in the degenerative nucleus pulposus and contributes to the degeneration and apoptosis of human nucleus pulposus cells. Mol Med Rep. 2017;16(4):4730-6. https://doi.org/10.3892/mmr.2017.7178

PMid:28791354

11. Kadow T, Sowa G, Vo N, Kang JD. Molecular basis of intervertebral disc degeneration and herniations: What are the important translational questions? Clin Orthop Relat Res. 2015;473(6):1903-12. https://doi.org/10.1007/ s11999-014-3774-8

PMid:25024024

12. Amin RM, Andrade NS, Neuman BJ. Lumbar disc herniation.
Curr Rev Musculoskelet Med. 2017;10(4):507-16. https://doi. org/10.1007/s12178-017-9441-4

13. Olmarker K, Rydevik B. Disc Herniation and sciatica; the basic science platform. In: Gunzburg R, Szpalski M, editor. Lumbar Disc Herniation. Philadelphia, PA: Lippincott Williams \& Wilkins; 2002. p. 31-7.

14. Splendiani A, Puglielli E, De Amicis R, Barile A, Masciocchi C, Gallucci M. Spontaneous resolution of lumbar disk herniation: Predictive signs for prognostic evaluation. Neuroradiology. 2004;46(11):916-22. https://doi.org/10.1007/ s00234-004-1232-0

PMid:15609071

15. Ala-KokkoL. Genetic riskfactorsforlumbar disc disease.Ann Med. 2002;34(1):42-7. https://doi.org/10.1080/078538902317338634 PMid:12014433

16. Paassilta P, Lohiniva J, Goring HH, Perala M, Raina SS, Karppinen J, et al. Identification of a novel common genetic risk factor for lumbar disk disease. JAMA. 2001;285(14):1843-9. https://doi.org/10.1001/jama.285.14.1843 PMid: 11308397

17. Feng $\mathrm{Y}$, Egan B, Wang J. Genetic factors in intervertebral disc degeneration. Genes Dis. 2016;3(3):178-85. https://doi. org/10.1016/j.gendis.2016.04.005 PMid:27617275

18. Mehrazin M, Vafaei SH. Surgical results in lumbar disc (analysis of 101 cases). Teb va Tazkieh. 2003;48:32-8.

19. Gleave JR, Macfarlane R. Cauda equina syndrome: What is the relationship between timing of surgery and outcome? $\mathrm{Br} J$ Neurosurg. 2002;16(4):325-8.

PMid: 12389883

20. Berbaum KS, Franken EA, Dorfman DD, Rooholamini SA Kathol MH, Barloon TJ, et al. Satisfaction of search in diagnostic radiology. Invest Radiol. 1990;25(2):133-40. https://doi. org/10.1097/00004424-199002000-00006

PMid:2312249

21. Berbaum KS, Dorfman DD, Franken EA Jr., Caldwell RT. Proper $\mathrm{ROC}$ analysis and joint ROC analysis of the satisfaction of search effect in chest radiography. Acad Radiol. 2000;7(11):94558. https://doi.org/10.1016/s1076-6332(00)80176-2

22. Xu BX, Liu CB, Wang RM, Shao MZ, Fu LP, Li YG, et al The influence of interpreters' professional background and experience on the interpretation of multimodality imaging of pulmonary lesions using 18F-3'-deoxy-fluorothymidine and 18F-fluorodeoxyglucose PET/CT. PLoS One. 2013;8(4):e60104. https://doi.org/10.1371/journal.pone.0060104 PMid:23565188

23. Hung-Tah Wu, Chang $\mathrm{CY}$, Chang $\mathrm{H}$, Yen $\mathrm{CC}$, Cheng $\mathrm{H}$, Chen PC, et al. Magnetic resonance imaging guided biopsy of musculoskeletal lesions. J Chin Med Assoc. 2012;75(4):160-6. PMid:22541144

24. AhnUM,AhnNU, BuchowskiJM, GarrettES, SieberAN, KostuikJP. Cauda equina syndrome secondary to lumbar disc herniation: A meta-analysis of outcomes. Spine. 2000;25(12):1515-22. https://doi.org/10.1097/00007632-200006150-00010 PMid: 10851100

25. Li H, Ma XL, Wang P. The immunopathological observation of lumbar disc herniation. Chine J Orthop. 2011;31(1):66-70.

26. Rose-Innes AP, Engstrom JW. Low back pain: An algorithmic approach to diagnosis and management. Geriatrics. 1998;53(10):26-8. PMid:9791195

27. Ma XL, Xu YQ, Zhang YX, Ma JX. Study of autoimmune factors in lumbar disc herniation. Zhongguo Xian Dai Shen Jing Ji Bing. 2004;4:291-6. 
28. Dimogerontas G, Paidakakos NA, Konstantinidis E. Voluminous free disk fragmentmimicking an extra dural tumor. Neurol Med Chir (Tokyo). 2012;52(9):656-8. https://doi.org/10.2176/nmc.52.656 PMid:23006881

29. Atlas SJ, Deyo RA. Evaluating and managing acute low back pain in the primary care setting. J Gen Intern Med. 2001;16(2):12031. https://doi.org/10.1111/j.1525-1497.2001.91141.x PMid:11251764

30. Weiler C, Nerlich AG, Zipperer J, Bachmeier BE, BoosN SSE award competition in basic science: Expression of major matrix metalloproteinases is associated with intervertebraldisc degradation and resorption. Eur Spine J. 2002;11(4):308-20. https://doi.org/10.1007/s00586-002-0472-0 PMid:12193991

31. Nerlich AG, Weiler C, Zipperer J, Narozny M, Boos N Immunolocalization of phagocytic cells in normal and degenerated intervertebral discs. Spine (Phila Pa 1976). 2002;27(22):248490. https://doi.org/10.1097/00007632-200211150-00012 PMid: 12435979

32. Haddadi K, Asadian L, Emadian O, Zare AH. Hydatid disease of the lumbar spine: A Report on pure spinal involvement with hydatid cysts. Neurosurg Q. 2015;25(1):128-30. https://doi. org/10.1097/wnq.0000000000000007

33. Pannucci CJ, Wilkins EG. Identifying and avoiding bias in research. Plast Reconstr Surg. 2010;126(2):619-25. https://doi. org/10.1097/prs.0b013e3181de24bc

PMid:20679844

34. Carragee EJ, Han MY, Suen PW, Kim D. Clinical outcomes after lumbar discectomy for sciatica: The effects of fragment type and annular competence. J Bone Joint Surg Am. 2003;85(1):102-8. https://doi.org/10.2106/00004623-200301000-00016

PMid:12533579

35. Wu SY, Wei TS, Chen YC, Huang SW. Vertebral osteomyelitis complicated by iliopsoas muscle abscess in an immunocompetent adolescent: Successful conservative treatment. Orthopedics. 2012;35(10):1576-80. https://doi. org/10.3928/01477447-20120919-34 PMid:23027502

36. Livesey JP, Sundaram S, Foster L. Laser discectomy versus lumbarepidural steroid injection: A randomised comparative study of two treatmentsfor sciatica. J Bone Joint Surg Br. 2000;82(S1):74.

37. Paesold G, Nerlich AG, Boos N. Biological treatment strategies for disc degeneration: Potentials and shortcomings. Eur Spine J. 2007;16(4):447-68. https://doi.org/10.1007/s00586-006-0220-y PMid:16983559

38. Tudor GR, Finlay D, Taub N. An assessment of inter-observer agreement and accuracy when reporting plain radiographs. Clin Radiol. 1997;52(3):235-8. https://doi.org/10.1016/ s0009-9260(97)80280-2

PMid:9091261

39. Ebeling $U$, Reulen HJ. Are there typical localisations of lumbar disc herniations? A prospective study. Acta Neurochir (Wien). 1992;117(3-4):143-8. https://doi.org/10.1007/bf01400611 PMid:1414514

40. Ajiboye RM, Drysch A, Mosich GM, Sharma A, Pourtaheri S.
Surgicaltreatmentofrecurrentlumbardiskherniation:Asystematic review and meta-analysis. Orthopedics. 2018;41(4):e457-69. https://doi.org/10.3928/01477447-20180621-01

PMid:29940051

41. Daoyou MA, Liang $\mathrm{Y}$, Wang $\mathrm{D}$, Liu Z, Zhang $\mathrm{W}$, Ma T, et al Trend of the incidence of lumbar disc herniation: Decreasing with aging in the elderly. Clin Interv Aging. 2013;8:1047-50. https://doi.org/10.2147/cia.s49698

PMid:23966775

42. Vialle LR, Vialle EV, Henao JE, Giraldo G. Lumbar disc herniation. Rev Bras Ortop. 2010;45(1):17-22. https://doi. org/10.1016/s2255-4971(15)30211-1

43. Scapinelli R. Lumbar disc herniation in eight siblings with a positive family history for disc disease. Acta Orthop Belg. 1993;59(4):371-6.

\section{PMid:8116369}

44. Matsui $\mathrm{H}$, Maeda A, Tsuji $\mathrm{H}$, Naruse $\mathrm{Y}$. Risk indicators of low back pain among workers in Japan. Association of familial and physical factors with low back pain. Spine (Phila Pa 1976). 1997;22(11):1242-7. https://doi. org/10.1097/00007632-199706010-00014

\section{PMid:9201863}

45. Videman T, Battié MC, Gibbons LE, Maravilla K, Manninen H, Kaprio J. Associations between back pain history and lumbar MRI findings. Spine (Phila Pa 1976). 2003;28(6):582-8. https:// doi.org/10.1097/01.brs.0000049905.44466.73

PMid:12642766

46. Chanapa P, Yoshiyuki T, Mahakkanukrauh P. Distribution and length of osteophytes in the lumbar vertebrae and risk of rupture of abdominal aortic aneurysms: A study of dry bones from Chiang Mai, Thailand. Anat Cell Biol. 2014;47(3):157-61. https:// doi.org/10.5115/acb.2014.47.3.157

PMid:25276474

47. Sakai D. Future perspectives of cell-based therapy for intervertebral disc disease. Eur Spine J. 2008;17(4):452-8. https://doi.org/10.1007/s00586-008-0743-5 PMid:19005704

48. Kandel R, Roberts S, Urban JP. Tissue engineering and the intervertebral disc: The challenges. Eur Spine J. 2008;17(4):48091. https://doi.org/10.1007/s00586-008-0746-2

PMid: 19005701

49. Morshed T, Haque S, Awwal A, Abedin N, Sultana S. Role of magnetic resonance imaging in the diagnosis of cervical disc herniation: Comparison with peroperative findings. Chattagram Maa-O-Shishu Hosp Med Coll J. 2014;13(2):59-62. https://doi. org/10.3329/cmoshmcj.v13i2.21071

50. Catherine JB, Norman GR, Coblentz CL. Effect of clinical history on the interpretation of chest radiographs in childhood bronchiolitis. Investig Radiol. 1993;28(3):214-7. https://doi. org/10.1097/00004424-199303000-00005

51. Myers AL, Hall M, Williams DJ, Auger K, Tieder JS, Statile A, et al. Prevalence of bacteremia in hospitalized pediatric patients with community-acquired pneumonia. Pediatr Infect Dis J. 2013;32(7):736-40. https://doi.org/10.1097/ inf.0b013e318290bf63

PMid:23518826 